\title{
Key issues in assessing the feasibility of reintroducing the great bustard Otis tarda to Britain
}

\author{
Patrick E. Osborne
}

\begin{abstract}
The great bustard is a globally-threatened species needing conservation action across Europe. This paper discusses key issues in the case for reintroducing the bird to Britain. Great bustards became extinct as a breeding species in Britain in 1832 probably as a result of hunting, agricultural change and inclement weather. The factors that caused the loss are no longer thought to operate. Suitable habitat exists in pockets across England and especially on Salisbury Plain where a large area is protected for military training and conservation purposes. The Plain combines short grass areas for lekking, long grassland for feeding and adjacent arable land for nesting. Pilot studies on arthropods in long grassland suggest that their density is sufficient for chick-rearing but the precautionary creation of additional food-rich areas among arable crops is recommended. Genetic studies indicate that Britain's bustards probably
\end{abstract}

belonged to the central European group and that restocking should not use birds from Iberia. Only Russia has sufficient birds to supply a reintroduction project and losses there through nest destruction are high. By rescuing eggs, artificially incubating them and transporting chicks to Britain, the project should have zero detriment to the donor population. Modelling indicates that 40 chicks will need to be brought to Britain for 5-10 years to build a founder population of 100 birds. Although focused on direct action in Britain, the project will promote grassland conservation across Europe and serve as a model for translocating bustards elsewhere.

Keywords Britain, captive breeding, extinction, great bustard, Otis tarda, population viability, reintroduction, Russia, translocation.

\section{Introduction}

The great bustard Otis tarda is a globally-threatened species of steppe and pseudo-steppe habitats with a world population of 31,000-37,000 individuals (Heredia et al., 1996; BirdLife International, 2004). Its Red List category (IUCN, 2003) is Vulnerable based on criteria A2c, because a population reduction of more than $30 \%$ is predicted within the next 10 years (BirdLife International, 2004). It is patchily distributed from Portugal, Spain and northern Africa, across central, southern and eastern Europe, southern Siberia and Mongolia to parts of eastern China (Morales \& Martín, 2003). The species has declined since the turn of the 19th century due to habitat loss, nest destruction, pesticide use, persecution through hunting, and collisions with power lines. A European Action Plan was adopted by the Council of Europe in 1996 (Heredia et al., 1996), and includes consideration of reintroduction projects in Britain, France and Poland. The case for restoring species in Britain is enshrined in legislation from the international to national

Patrick E. Osborne School of Biological and Environmental Sciences, University of Stirling, Stirling, FK9 4LA, UK. E-mail peo1@stir.ac.uk

Received 4 December 2003. Revision requested 2 June 2004. Accepted 13 August 2004. level. Internationally, Article 8(f) of the Convention on Biological Diversity requires Contracting Parties to rehabilitate and restore degraded ecosystems and promote the recovery of threatened species through the development and implementation of plans or other management strategies. At European level, the EC Habitats Directive 92/43/EEC obliges Member States to consider the feasibility of restoring species that have become locally extinct. Nationally, the importance of biodiversity conservation has been given statutory basis under Section 74 of the Countryside and Rights of Way Act 2000 that requires government departments to have regard for biodiversity and to take positive steps to further the conservation of listed species and habitats. Apart from the great auk Pinguinus impennis (extinct since the 1840s) and the migratory Kentish plover Charadrius alexandrinus (last nested in Lincolnshire in 1979), the great bustard is the only bird species that bred regularly in Britain within the last 200 years but no longer does so. After a detailed consultation phase on the case for reintroduction (Osborne, 2002), based on IUCN guidelines (IUCN, 1995), the British Government approved a licence in November 2003 for a 10-year trial reintroduction of the great bustard to Britain. The first birds were brought to Britain in August 2004 and 22 were released the following month. This paper summarizes the evidence 
put forward to answer some of the most challenging issues in the guidelines. The underlying argument is that a reintroduction attempt is feasible and the only way to learn more about bustard ecology in Britain, which was poorly documented prior to extinction.

\section{Issue 1. History and reason for extinction in Britain}

Bones from Gough's Old Cave, dating from 9,300-12,300 $\mathrm{BP}$, are the earliest evidence of the great bustard in Britain (Harrison, 1989) and there can be little doubt that it is a native species. Written records begin with a household account from the Borough of King's Lynn (1371), hunting regulation from Yorkshire (1512), recorded occurrence in Scotland (1526), and notes in household books from Norfolk in 1527 and 1530 (Yarrell, 1882-4; Stevenson \& Southwell, 1890). The species was apparently widespread in the 16th century and both the bird and its eggs were taken for food (Yarrell, 1882-4). Later, around 1670, Sir Thomas Browne described the bird as 'not unfrequent' in Norfolk and an advertisement from 1712 for an estate in Essex noted 'all game in great plenty, even to the bustard and pheasant' (Yarrell, 1882-4). In other areas the birds were by then scarce, Morton noted in 1712 that he had never heard of more than two bustards in Northamptonshire (in Yarrell, 1882-4). Evidence for a decline in British bustards begins around the mid1700s and they had become 'exceedingly scarce in their southern haunts' by the end of the 18th century (Yarrell, 1882-4). Although a statute was enacted in 1775 to prohibit spring and summer hunting (Collar, 1979), great bustards dwindled to extinction, the last breeding dates for Britain being 1830 for Norfolk and 1832 for Suffolk (Morales \& Martín, 2003).

While the exact reason for the great bustard's extinction is not known (Collar, 1979), the historical literature suggests possible causes and facilitates judgement on the likelihood of similar events occurring today. There is no historical evidence of disease, pollution, poisoning, competition or predation. Four other causes may have played a part either alone or in concert: field enclosure, agricultural mechanization, hunting for food and trophies, and climate change.

In 1821 Graves wrote: 'the enclosing and cultivating [of] those extensive downs and heaths in various parts of Great Britain, on which formerly this noble species was seen in large flocks, threatens within a few years to extirpate the bustard from this country' (quoted in Thomas, 2000). The enclosure of common land through Parliamentary Acts, however, was a drawn out process in Britain lasting from 1603 to 1903, although the great majority of Acts date from 1760 to 1820 (Pollard et al., 1974). By 1700 over half of the British farmland was still unenclosed (Burton, 1995) and enclosure was by no means uniform across the country; some areas, including large tracts of Salisbury Plain, were never enclosed. Enclosure alone is therefore unlikely to have caused extinction.

Stevenson (1870) thought that changes in agricultural practice brought about the extirpation of bustards in Norfolk. Before the decline, hen bustards frequently laid their eggs in winter-sown rye that had been handbroadcast. Wheat gradually replaced rye and its high value inspired the invention of the seed-drill, which minimized wastage and facilitated weeding, either by parties of children or later by horse-hoeing. In the former case eggs were collected for incubation at home or for trophies, and in the latter nests were destroyed. He notes 'thus, every nest made by a bustard in a wheat-field was sure to be discovered' (Stevenson, 1870). The advent of mechanical hoes also permitted inter-row cultivation, a practice unknown to medieval farmers ( $\mathrm{O}^{\prime}$ Connor \& Shrubb, 1986), which left a smaller area of the land untilled and available for breeding birds.

Hudson (1923) states that the great bustard was 'deliberately extirpated' and 'pursued in that ruthless manner that seems to indicate on the part of the persecutors a fixed relentless determination to wipe the species out'. Coward (in Hudson, 1923) adds 'perhaps more than either [the spread of cultivation or increase in human population] improvement in sporting guns, swept them away'. On taxidermy, Knight (1866) notes that 'when the mania for real British specimens of birds was prevalent, the bustards suffered not a little. We know a collector who, about the year 1816, had nine dead bustards before him together'.

While these anthropogenic factors were affecting bustards, Britain's climate was also generally unfavourable. The period 1250-1850 saw deterioration in Europe's climate and the Little Ice Age of 1550-1700 brought especially cold winters and cool springs, conditions that would almost certainly have increased winter mortality and reduced breeding. Significantly, great bustards became extinct as a breeding species in France, southern Sweden and northern Italy in the mid to late 1800s, shortly after their extinction in Britain (Isakov, 1974), suggesting that factors outside Britain were involved.

A key issue is whether these factors could still be operating in Britain today. Hunting is well regulated and the illegal killing of bustards is unlikely to pose a serious threat. Agriculture, although highly mechanized, employs far fewer people on the land to disturb nesting birds and destroy eggs. If the Little Ice Age were instrumental in the extinction of great bustards, that threat has also gone as the British climate has warmed over the last 200 years (Burton, 1995). Thus the factors that most likely caused the great bustard's extinction in Britain no longer 


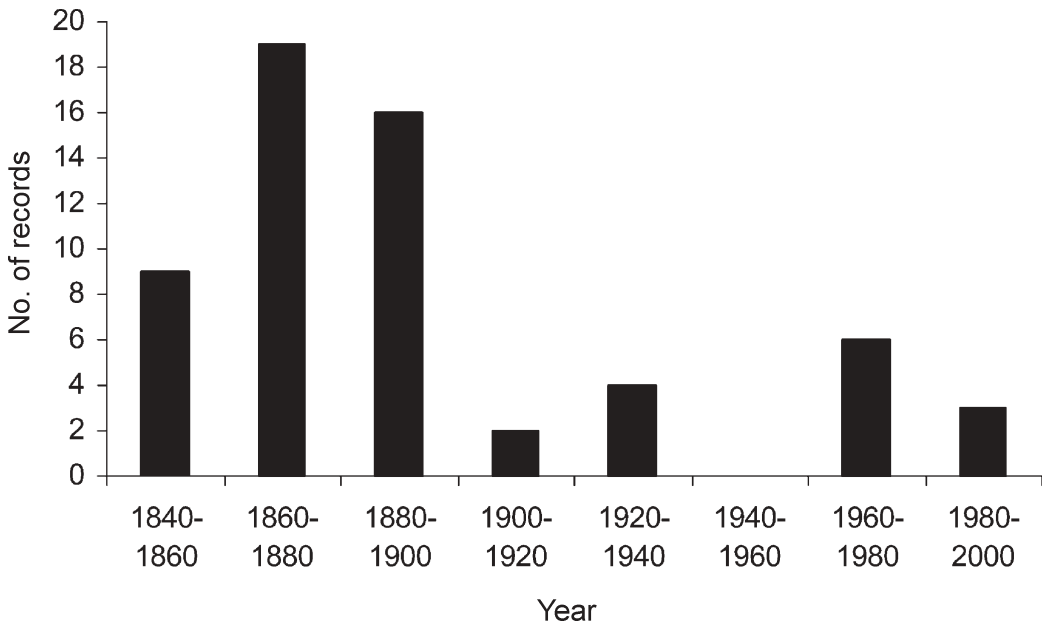

Fig. 1 Number of occasions on which great bustards have visited Britain in 20-year periods from 1840 to 2000 (based on data in Naylor 1996, 1998). operate (although, of course, new threats may be present). Despite this, great bustards are unlikely to re-establish themselves naturally due to low numbers and population fragmentation in mainland Europe. The number of vagrant birds reaching Britain has declined since extinction in the early 1800s (Fig. 1) and too few birds visit the country to form a viable population. Reintroduction is therefore the only way in which great bustards could return to Britain as a breeding species in the foreseeable future.

\section{Issue 2. Availability of suitable habitat}

Great bustards were formerly widespread in England, key areas being the Wessex Downs, Brecklands in East Anglia, North Yorkshire Moors and along the coasts of Norfolk, Kent and the Thames estuary. Many of these have changed greatly since the bustard's extinction but pockets of visually suitable habitat are still widespread and could be occupied through expansion from a core area. Bustards are slow breeders and population expansion would take place over decades rather than years, allowing ample time for habitat creation as opportunities arise. The best core area is probably Salisbury Plain, a large area of protected calcareous grassland in the heart of southern England. Over $50 \%$ of the area carries the EU designation Special Protection Area, and parts of the Plain are classed as a Special Area of Conservation. These designations are effectively permanent. In addition, the whole of the Salisbury Plain Training Area (SPTA) of c. 38,000 ha is used by the military and covered by an integrated management plan for wildlife that ensures that any area with conservation interest is managed sympathetically. The SPTA is also included within the terms of a Declaration of Intent between the Ministry of Defence (MoD) and English Nature (signed in 1992, 1996 and 2002). This effectively recognizes that while the prime purpose of the SPTA is military training, nature conservation interests will be considered in all management activities. Similarly, a Memorandum of Understanding was signed in 1995 between the Department of the Environment (now DEFRA) and the MoD with respect to land owned or occupied by the MoD and defined as a European site under the Habitats Directive. Again, this recognizes that the prime purpose of the land is for military training but that the European Directives impose obligations on the Government with regard to the conservation of natural habitats and species.

The short grassland areas of the SPTA provide bustard lekking grounds that are visually comparable with favoured areas in Portugal such as Castro Verde and with parts of Saratov Oblast, Russia. As female great bustards nest close to the lek and exhibit high natal site fidelity (Alonso \& Alonso, 1992; Alonso et al., 2000; Morales et al., 2000) adjacent nesting habitat is also required. Although originally nesting in tall grassland, the species now favours cereal crops, and historical records from Britain suggest a preference for rye (Stevenson, 1870). Fortunately, the cropped areas surrounding the SPTA provide the right vegetation structure for nesting great bustards and are similar to comparable nesting areas in Iberia. Intensively farmed cereal crops are, however, generally poor in invertebrates, a probable cause of widespread declines in farmland birds (Fuller et al., 1995; Wilson et al., 1999; Donald et al., 2001). Although adult great bustards eat largely a vegetarian diet $(90.4 \%$ green plant material, $2.7 \%$ seeds and $6.9 \%$ invertebrates in Spain (Lane et al., 2000), invertebrates are essential for the chicks for the first 3 months, when growth rates are highest (Litzbarski \& Litzbarski, 1996; Lane et al., 2000; Morales et al., 2002). Unfavourable vegetation structures and low stocks of arthropods are cited reasons for the extremely high mortality rate of great bustard chicks in eastern Germany (Litzbarski 
Table 1 Arthropod biomass captured on 100 sweeps of a net through vegetation in Britain, Germany and Russia during the period that great bustards would be rearing their young. British data gathered by the Great Bustard Group.

\begin{tabular}{llll}
\hline Location (source) & Habitat & Range (g per 100 sweeps) & Mean (g per 100 sweeps) \\
\hline Salisbury Plain (this study) & Rough grassland July 2002 & $2.3-7.1$ & $4.3-7.0$ \\
& Rough grassland July 2003 & - & 4.7 \\
Buckow, Germany (Block et al., 1993) & Intensive grassland & - & 2.9 \\
& Extensive grassland (8-10 years old) & $1.1-20.9$ \\
Saratov, Russia (Khrustov \& & Winter wheat & $3.1-41.3$ \\
Litzbarski, 2000) & Virgin steppe & $0.9-7.4$ \\
& Fallow land (>6 years old) & $0.9-117.5$ \\
\hline
\end{tabular}

\& Litzbarski, 1993, 1996). The solution for Britain may lie in the proximity of rough grassland areas, rich in arthropods, to cereals, a situation that exists on Salisbury Plain and mimics mixed (often rotational) farming in more extensive systems. In Germany $4.5 \mathrm{~g}$ of invertebrate biomass per 100 sweeps of a sweep net has been used as a crude indicator of food availability for chick rearing (Litzbarski et al., 1987; Litzbarski \& Litzbarski, 1993). Litzbarski's method was used at 10 grassland sites on Salisbury Plain in 2002 and 2003 as a pilot study on food availability (Table 1). Although arthropod catches were lower in 2002 than 2003 due to a cool and wet summer, overall Salisbury Plain just exceeded the threshold of $4.5 \mathrm{~g}$ per 100 sweeps. Britain lies at the edge of the great bustard's range and has probably never been the best breeding area, nor one in which every year is suitable for successful breeding. It appears that Salisbury Plain's rough grasslands probably have sufficient chick food in an average year, but it would be advisable to take the precautionary approach and also manage supplementary areas for bustards. Increased arthropod abundance may be achieved in three ways. Firstly, arable land that is 'set aside' with no specific management prescription for bustards is likely to increase in beetle diversity and density (Desender \& Bosmans, 1998), probably because fewer pesticide applications are used (e.g. Moreby et al., 1994). Secondly, the same result may be achieved by establishing unsprayed 'conservation headlands' within arable fields (Chiverton \& Sotherton, 1991). Thirdly, plots may specifically be created for great bustards, as has been done in Austria (Kollar, 1993). In the context of Salisbury Plain, 2-3 ha plots may be established on the margins of arable land, planted with low density cereals and green forage plants such as turnip or kale for the winter. The birds may choose to nest in these and would almost certainly use them for feeding.

Opportunities for habitat creation in England are also likely through current proposals for reform of farm subsidies to be implemented from 2005 onwards. While details are still being worked out, the reforms will provide a new single payment to farmers that is not linked to production but to compliance with environmental and other standards. Of particular relevance may be the biodiversity enhancements proposed under the Entry Level Scheme that could support winter stubbles, wild bird cover crops, grass margins on arable land, and nesting plots on winter cereals (DEFRA, 2004).

\section{Issue 3. Suitable donor population}

The genetics of British great bustards have not been studied and it is questionable whether this is possible. Most preserved specimens date from after the extinction and those collected earlier in the 19th or late 18th centuries tend to be poorly documented and of doubtful origin. It is, however, reasonable to assume that British bustards formed part of the wider central and eastern European population currently found, for example, in Germany, Hungary, Russia and Ukraine. Pitra et al. (2000) used mtDNA to study the genetic relationships among great bustards from Spain, Germany, Hungary, Slovakia and Russia. They identified 11 different haplotypes and none was shared among the populations in Spain and those elsewhere in Europe. There are thus two geographic clusters (or evolutionary significant units; ESUs) within the O. t. tarda subspecies: on the Iberian Peninsula and the European mainland (Pitra et al., 2000). These probably arose because the Pyrenees acted as an effective barrier to intermixing when bustards emerged from their southern and eastern refugia after the last ice age (Blondel \& Aronson, 1999). It is known that birds from Germany still occasionally migrate as far as the UK in response to harsh winters (Dornbusch, 1996), whereas no bird of Iberian origin has ever been recorded in Britain. Pitra et al. (2000) advise that 'managers [should] seek individuals from within the same ESU when augmentation of threatened populations is necessary', ruling out Iberian birds as the source for a reintroduction to Britain on a genetic basis.

Among mainland European countries, only Russia has a large number of great bustards, especially in the 
Table 2 Autumn census results for great bustards on $12,000 \mathrm{~km}^{2}$ of Saratov Oblast territory, conducted by Russian Academy of Science staff. Data from A. Khrustov, pers. comm.

\begin{tabular}{|c|c|c|c|c|c|}
\hline & 1998 & 1999 & 2000 & 2001 & 2002 \\
\hline Transect length $(\mathrm{km})$ & 6,921 & 7,200 & 6,850 & 6,910 & 6,733 \\
\hline No. of observer hours & 483 & 555 & 463 & 589 & 520 \\
\hline $\begin{array}{l}\text { No. of great bustards } \\
\text { counted }\end{array}$ & 1,859 & 2,175 & 2,328 & 2,243 & 2,108 \\
\hline
\end{tabular}

Saratov region where the population was estimated at 5,900 in 1999 and annual sample censuses show numbers to be more or less stable (Table 2; A. Khrustov, pers. comm.). The majority of Saratov's bustards breed in winter wheat or on fallow land and the greatest threat to the population is the destruction of nests through agricultural operations. Land is cultivated up to seven times during the spring using a tractor-drawn chain harrow that can destroy up to $80 \%$ of bustard nests (Flint \& Mishchenko, 1991). Attempts have been made since 1982 to collect eggs from these nests for artificial rearing (Ponomareva, 1983) but the reporting and monitoring of this work has not been comprehensive. Table 3 shows the activities during the last 5 years; in all cases the reared birds have been humanized and could not be released with any reasonable expectation of success.

The conservation of bustards in Saratov will require international assistance focused on changing agricultural practices, and this will inevitably take time. Meanwhile, the eggs that are being lost could be rescued and used for conservation purposes. Taking the pessimistic view that Saratov has only 4,000 birds, c. 2,016 would be breeding females, based on the population data in Lane \& Alonso (2001) and Onrubia et al. (1998). Using clutch size data from Saratov would give a figure of 2,750 eggs per year (from a single clutch) for these 2,016 females. Even assuming losses as low as 20\% (rather than Flint \& Mishchenko's 80\%) suggests there are more than 500 eggs at risk each year. Given the relatively modest needs for the British project, sourcing birds from Russia is viable in the short- to medium-term with zero detriment to the donor population. In addition, parallel conservation work in Russia and the sharing of expertise would bring considerable benefits.

\section{Issue 4. Establishing a founder population in Britain}

The captive breeding of bustards is difficult and no one has succeeded with great bustards to the extent required for reintroduction (Mártin et al., 1996). If reintroduction into Britain is to be achieved, it will be through the translocation of young raised from eggs gathered in the wild. This proposal is in marked contrast to a previous,
Table 3 Numbers of chicks raised from rescued eggs in Saratov Oblast during 1998-2002, and their fate. Data supplied by A. Khrustov, pers. comm.

\begin{tabular}{|c|c|c|}
\hline Year & $\begin{array}{l}\text { No. chicks } \\
\text { raised }\end{array}$ & Fate \\
\hline 1998 & 2 & $\begin{array}{l}\text { Wing-tagged and released at } 2 \text { months } \\
\text { old, fate unknown }\end{array}$ \\
\hline 1999 & 64 & $\begin{array}{l}\text { Two chicks released (fate unknown); } \\
62 \text { chicks supplied to a captive breeding } \\
\text { scheme in Kharkiv, Ukraine }\end{array}$ \\
\hline 2000 & 89 & Sent to Ukraine (as above) \\
\hline 2001 & 38 & $\begin{array}{l}\text { Sent to Russian Federation zoos in Oryol, } \\
\text { Penza and Kalmika }\end{array}$ \\
\hline 2002 & 8 & Sent to Penza Zoo, Russian Federation \\
\hline
\end{tabular}

unsuccessful plan to reintroduce bustards to Britain through captive breeding (Collar \& Goriup, 1980). Egg rescue schemes have been in place in Russia, Germany and Hungary since the 1970s but the most successful outcomes are from the German project in Buckow and the Hungarian project at Dévaványa (Table 4). Overall, $28.8 \%$ of eggs collected in Germany produced birds for release at about 60 days old and the corresponding figure for Hungary was $22.8 \%$. Poor hatchability arises from rough handling of eggs in transportation to the rearing station and incorrect incubation conditions. Recent work in Russia has achieved 76.3\% (58/76) hatching success, exceeding the interannual range of $36.2-57.8 \%$ from Hungary in 1979-1988 (Farago, 1989) and suggesting scope for improvement through sound avicultural practice.

Although stochastic models are generally preferred for population modelling (Streich et al., 1996; Osborne in Onrubia et al., 1998; Lane \& Alonso, 2001), so little is known about the impact of environmental variability on success in Britain that transferring data from other countries could be misleading (Osborne, 2002). While work is progressing to improve population viability analyses for bustards, it is safest here to use a simple deterministic model of population growth in Britain to illustrate the likely number of birds that need to be translocated.

On average, $75 \%$ of eggs are fertile and $72 \%$ of these hatch if collected from first clutches (Farago, 1989; Litzbarski \& Litzbarski, 1993). Practicalities dictate that the maximum number of chicks that can be brought to Britain at one time is 40 . Thus it will be necessary to collect 75 eggs each year from threatened nests. In Hungary an average of $48 \%$ of chicks from first clutches survive until release. The figure is higher (59\%) in Buckow, Germany (Litzbarski \& Litzbarski, 1993). Litzbarski \& Litzbarski (1993) showed that in Germany male survival is better than female survival prior to release, largely due to mortality during the first 10 days. Using their data adjusts the Hungarian figures to $53 \%$ for 


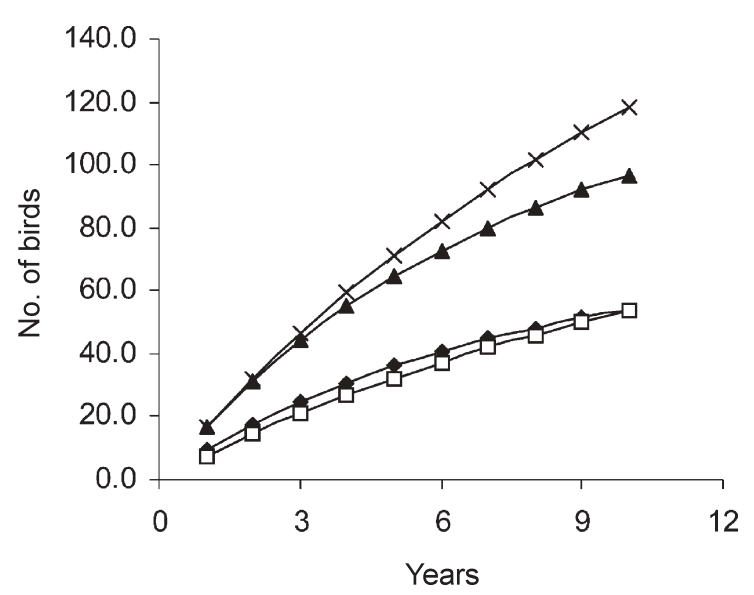

males and $43 \%$ for females as a conservative estimate of pre-release survival. For an optimistic estimate, I assume 95\% survival for both sexes. Only poor data are available on survival immediately post release; Litzbarski \& Litzbarski (1993) give losses as $11.5 \%$, and thus $88 \%$ survival is used here as a starting estimate. The best data on survival after the 1st year (i.e. adult survival) in the wild come from studies in Spain, and $87 \%$ for males and $92 \%$ for females is used here as a starting point (Lane \& Alonso, 2001).

A simple deterministic model built from the above data shows that after 10 years of releases (the maximum planned), the populations of both males and females will grow to 54 individuals each, assuming conservative prerelease survival and no breeding in the wild in Britain (Fig. 2). With optimistic estimates of pre-release survival, these figures increase to 118 females and 97 males. Note that because the breeding age differs in males (5 years) and females (3 years), the effective sex-ratio at first breeding is 5 males to 18 females with conservative survival, although the estimated populations will be approximately equal at 36 males and 32 females. This skew is appropriate for great bustards that are promiscuous or polygamous with perhaps only a third of sexually mature males actually mating (Lane \& Alonso, 2001). Projecting the conservative model (but note reservations about lack of appropriate data for Britain) shows that it $\ldots$ Males, conservative prerelease survival

$\rightarrow \square$ Females, conservative pre-release survival

$\neg$ Males, optimistic prerelease survival

$\leftarrow$ Females, optimistic prerelease survival

Fig. 2 Modelled build-up of the released great bustard population assuming conservative (53\% male, $43 \%$ female) or optimistic ( $95 \%$ both sexes) pre-release survival. The model assumes no breeding.

would take 40 years without breeding before there are no males left (four females would survive to this point). Although a negative viewpoint, it does emphasize the time-scale over which habitat improvements could be made should breeding not occur. The weakest data are for post-release survival but even if this decreased to only $50 \%$ there would still be 31 males and 30 females remaining after 10 years and the population could persist for 35 years without breeding (conservative model).

Once augmentation has stopped after a maximum of 10 years, the population will lose $c .10$ birds per year due to adult mortality and thus recruitment needs to be $>10$ birds from around 50 females ( 0.2 chicks per female) for the population to grow. Accurate figures for productivity in the wild are scarce but data gathered by Alonso \& Alonso (1990) from five Spanish sites indicate 0.11-0.57 chicks per female. In another study Ena et al. (1987) found 0.44 chicks per female, while Morales et al. (2002) reported 0.14 chicks per female in a dense population in Spain. As life history parameters are closely linked to environment, it cannot be assumed that data obtained from elsewhere will apply to Britain and almost nothing is known about bustard population dynamics in the country prior to extinction. However, these data suggest that a reintroduced population would grow at a slow rate after augmentation ceases. This is not a flaw in the project but a facet of the species' biology.

Table 4 Breeding success data from great bustard projects in Germany and Hungary, mainly based on Farago (1989) and Litzbarski \& Litzbarski (1993).

\begin{tabular}{|c|c|c|c|c|c|c|c|c|}
\hline Location & Period & No. clutches & No. eggs & $\%$ fertile & No. hatched & $\%$ hatched & $\begin{array}{l}\text { No. chicks } \\
\text { released }^{1}\end{array}$ & $\begin{array}{l}\text { \% chicks } \\
\text { released }^{1}\end{array}$ \\
\hline Buckow, Germany & 1979-1988 & 443 & 785 & 73.5 & 385 & 49.0 & 226 & 58.7 \\
\hline Dévavány, Hungary & 1979-1988 & 764 & $1485^{2}$ & $75-80^{3}$ & 684 & 46.1 & - & - \\
\hline Dévavány, Hungary & 1983-1988 & - & - & - & 432 & - & 204 & 47.2 \\
\hline
\end{tabular}

${ }^{1}$ Survival measured to 60 days old.

${ }^{2}$ Omits two eggs for which data were not available, therefore the mean clutch was 1.95 eggs.

${ }^{3}$ Data from Palnik (1993). 


\section{Conclusion}

Reintroducing great bustards to Britain is feasible and without detriment to the donor population or recipient ecosystem, a view endorsed by the granting of a trial licence by the British government. Indeed, without a trial attempt and monitoring, it is doubtful whether issues such as habitat availability and carrying capacity, or effects of disturbance in Britain's crowded land, could ever be addressed. Taking a wider perspective, the bird is also a flagship species for grassland conservation and a reintroduction project would promote this much underrated habitat and contribute to the vision of re-establishing a grassland corridor across Europe (McCloskey, 1995). Aside from the direct aim of establishing a self-sustaining population in Britain, practical experience of bustard translocations is important in wider conservation terms. Great bustards are absent from large areas that appear suitable both from ground surveys (Lane et al., 2001) and modelling work based on satellite data (Osborne et al., 2001; Suárez-Seoane et al., 2002). The explanation is that both males and females show interannual fidelity to lek and nest sites (Alonso et al., 2000; Morales et al., 2000) and exhibit strong conspecific attraction. As a result, 'dispersing' individuals concentrate in areas that are already occupied and rarely form new leks in vacant suitable habitat (Morales et al., 2001). This slow (or even absent) natural colonization potential could bring disaster for European bustards facing rapid climate change and habitat loss. It is the probable reason why bustards are slow to recover from overhunting and other adverse conditions even when the threat has been removed. On the other hand, individuals could be successfully translocated if the techniques for moving birds and imprinting them on these vacant areas are perfected. Among the many challenges ahead for bustard reintroduction projects, building a better understanding of these avicultural issues is one of the foremost.

\section{Acknowledgements}

This paper is based on information gathered for the licence submission to government, commissioned by the Great Bustard Group. I would especially like to thank the Chairman, Dave Waters, for inviting me to write the report. Data from Russia were kindly provided by Dr Anatoly Khrustov and reports were translated by Tatiana Osborne. Valuable information was also supplied by Clive Bates, Ian Carter, James Ferguson-Lees, Paul Goriup, Tatiana Kapranova, Alison Martin, Paul Toynton and two anonymous referees. Flights to and from Russia were generously provided at concessionary rates by British Airways. I was supported by grants from the Rural Trust to the Great Bustard Group, and by the Carnegie Trust.

\section{References}

Alonso, J.C. \& Alonso, J.A. (eds) (1990) Parámetros Demográficos, Selección de Hábitat y Distribución de la Avutarda (Otis tarda) en Tres Regiones Españoles. ICONA, Madrid, Spain.

Alonso, J.C. \& Alonso, J.A. (1992) Male-biased dispersal in the great bustard Otis tarda. Ornis Scandinavica, 23, 81-88.

Alonso, J.C., Morales, M.B., Alonso, J.A. \& Martín, E. (2000)

Partial migration, and lek and nesting area fidelity in female great bustards. Condor, 102, 127-136.

BirdLife International (2004) Threatened Birds of the World 2004. CD-ROM. BirdLife International, Cambridge, UK.

Blondel, J. \& Aronson, J. (1999) Biology and Wildlife of the Mediterranean Region. Oxford University Press, Oxford, UK.

Burton, J.F. (1995) Birds and Climate Change. Biddles, Guildford, UK.

Chiverton, P.A. \& Sotherton, N.W. (1991) The effects on beneficial arthropods of the exclusion of herbicides from cereal crop edges. Journal of Applied Ecology, 28, 1027-1039.

Collar, N.J. (1979) The great bustard in Britain and Portugal. In Symposium Papers on the Great Bustard and the Houbara Bustard (ed. N.J. Collar), no pagination. CIC and Game Conservancy, Fordingbridge, UK.

Collar, N.J. \& Goriup, P.D. (1980) Problems and progress in the captive breeding of great bustards Otis tarda in quasi-natural conditions. Avicultural Magazine, 86, 131-140.

DEFRA (2004) Common Agricultural Policy - Reform. Http:/ / www.defra.gov.uk/farm/capreform/index.htm [accessed 15 July 2004].

Desender, K. \& Bosmans, R. (1998) Ground beetles (Coleoptera, Carabidae) on set-aside fields in the Campine region and their importance for nature conservation in Flanders (Belgium). Biodiversity and Conservation, 7, 1485-1493.

Donald, P.F., Green, R.E. \& Heath, M.F. (2001) Agricultural intensification and the collapse of Europe's farmland bird populations. Proceedings of the Royal Society of London, Series $B, 268,25-29$.

Dornbusch, M. (1996) Situation und Schutz der Grosstrappe (Otis. t. tarda L., 1758) in Sachsen-Anhalt. Naturschutz und Landschaftsplege in Brandenburg. Internationaler Workshop: Conservation and Management of the Great Bustard in Europe, Heft 1-2, 28-29.

Ena, V., Martinez, A. \& Thomas, D.H. (1987) Breeding success of the great bustard Otis tarda in Zamora Province, Spain in 1984. Ibis, 129, 364-370.

Farago, S. (1989) Evaluation of the Ten-year Work at Dévaványa Conservation Area Bustard Rescue Station. Department of Wildlife Management, University of Forestry and Timber Industry, Sopron, Hungary.

Flint, V.E. \& Mishchenko, A.L. (1991) The great bustard in the USSR: status and conservation. In The Conservation of Lowland Dry Grassland Birds in Europe (eds P. Goriup, L.A. Batten \& J.A. Norton), pp. 89-90. JNCC, Peterborough, UK.

Fuller, R.J., Gregory, R.D., Gibbons, D.W., Marchant, J.H., Wilson, J.D. \& Carter, N. (1995) Population declines and range contractions among lowland farmland birds in Britain. Conservation Biology, 9, 1425-1441.

Harrison, C.J.O. (1989) Bird remains from Gough's Old Cave Cheddar, Somerset. Proceedings of the University of Bristol Speleological Society, 18, 409-411.

Heredia, B., Rose, L. \& Painter, M. (1996) Globally Threatened Birds in Europe. Council of Europe Publishing, Strasbourg, France.

Hudson, W.H. (1923) Rare, Vanishing and Lost British Birds. Dent, London, UK. 
Isakov, Y.A. (1974) Present distribution and population status of the great bustard Otis tarda Linnaeus. Journal of the Bombay Natural History Society, 71, 433-444.

IUCN (1995) Guidelines for Re-introductions. IUCN, Gland, Switzerland.

IUCN (2003) 2003 IUCN Red List of Threatened Species. IUCN, Gland, Switzerland [http:/ / www.redlist.org, accessed 23 September 2004].

Knight, C. (ed.) (1866) Natural History or Second Division of The English Cyclopaedia. Volume I. Knight and Co., London, UK.

Kollar, H.P. (1993) Theory and Practice of Managed Plots for the Great Bustard. Unpublished manuscript held by the IUCN Bustard Specialist Group, c/o NatureBureau International, Newbury, UK.

Lane, S.J. \& Alonso, J.C. (2001) Status and extinction probabilities of great bustard (Otis tarda) leks in Andalucía, southern Spain. Biodiversity and Conservation, 10, 893-910.

Lane, S.J., Alonso, J.C., Alonso, J.A. \& Naveso, M.A. (2000) Seasonal change in diet and diet selection of great bustards (Otis t. tarda) in north-west Spain. The Journal of Zoology, 247, 201-214.

Lane, S.J., Alonso, J.C. \&. Martín, C.A. (2001) Habitat preferences of great bustard Otis tarda flocks in the arable steppes of central Spain: are potentially suitable areas unoccupied? Journal of Applied Ecology, 38, 193-203.

Litzbarski, B. \& Litzbarski, H. (1993) Great Bustard Preservation Work by the Nature Conservation Station Buckow in Eastern Germany. Unpublished manuscript held by the IUCN Bustard Specialist Group, c/o NatureBureau International, Newbury, UK.

Litzbarski, B. \& Litzbarski, H. (1996) Der Einfluss von Habitatstruktur und Entomofauna auf die Kükenaufzucht bei der Grosstrappe (Otis. t. tarda L., 1758). Naturschutz und Landschaftsplege in Brandenburg. Internationaler Workshop: Conservation and Management of the Great Bustard in Europe, Heft 1-2, 59-64.

Litzbarski, H., Litzbarski, B. \& Petrick, S. (1987) Zur Ökologie und zum Schutz der Großtrappe (Otis tarda L.) im Bezirk Potsdam. Acta Ornithoecologia, 1, 199-244.

Martín, E., Alonso, J.A., Alonso, J.C. \& Morales, M. (1996) Evaluation of captive breeding as a method to conserve threatened great bustard (Otis tarda) populations. In Conservación de las Aves Esteparias y su Habitat (eds J.F. Gutierrez \& J. Sanz-Zuasti), pp. 131-136. Junta de Castilla y León, Valladolid, Spain.

McCloskey, C. (1995) PEBLDS Explained: A Guide for IUCN Members to the Pan-European Biological and Landscape Diversity Strategy. IUCN, Gland, Switzerland.

Morales, M.B., Alonso, J.C. \& Alonso, J. (2002) Annual productivity and individual female reproductive success in a great bustard Otis tarda population. Ibis, 144, 293-300.

Morales, M.B., Alonso, J.C., Alonso, J.A. \& Martín, E. (2000) Migration patterns in male great bustards (Otis tarda). Auk, 117, 493-498.

Morales, M.B., Jiguet, F. \& Arroyo, B. (2001) Exploded leks: what bustards can teach us. Ardeola, 48, 85.

Morales, M.B. \& Martín, C.A. (2003) Otis tarda great bustard. BWP Update, 4, 217-232.

Moreby, S.J., Aebischer, N.J., Southway, S.E. \& Sotherton, N.W. (1994) A comparison of the flora and arthropod fauna of organically and conventionally grown winter wheat in southern England. Annals of Applied Biology, 125, 13-27.

Naylor, K.A. (1996) A Reference Manual of Rare Birds in Great Britain and Ireland. Volume 1. Privately published.
Naylor, K.A. (1998) A Reference Manual of Rare Birds in Great Britain and Ireland. Volume 2. Privately published.

O'Connor, R.J. \& Shrubb, M. (1986) Farming and Birds. Cambridge University Press, Cambridge, UK.

Onrubia, A., Sáenz de Buruaga, M., Osborne, P., Baglione, V., Purroy, F.J., Lucio, A.J. \& Campos, M.A. (1998) Viabilidad de la Poblacion Navarra de Avutardes. Unpublished Report, Consultora de Recursos Naturales, S.L., Navarra, Spain.

Osborne, P.E. (2002) Application to the Department for Environment, Food and Rural Affairs for a Licence to Re-introduce Great Bustards Otis tarda to Britain. Unpublished Report, Great Bustard Group, Salisbury, UK.

Osborne, P.E., Alonso, J.C. \& Bryant, R.G. (2001) Modelling landscape-scale habitat-use using GIS and remote sensing: a case study with great bustards. Journal of Applied Ecology, 38, 458-471.

Pitra, C., Lieckfeldt, D. \& Alonso, J.C. (2000) Population subdivision in Europe's great bustard inferred from mitochondrial and nuclear DNA sequence variation. Molecular Ecology, 9, 1165-1170.

Pollard, E., Hooper, M.D. \& Moore, N.W. (1974) Hedges. Collins, London, UK.

Ponomareva, T.S. (1983) Die Restitution natürlicher Populationen der Großtrappe (Otis tarda L.) in der USSR. 4. Symposium über die Großtrappe (Otis tarda). Eberswalde, Germany.

Stevenson, H. (1870) The Birds of Norfolk. Volume 2. Van Vorst, London \& Norwich, UK.

Stevenson, H. \& Southwell, T. (1890) The Birds of Norfolk. Volume 3. Gurney and Jackson, London \& Norwich, UK.

Streich, W.J., Pitra, C., Litzbarski, H. \& Quaisser, C. (1996) Zur Populationsdynamik der Grosstrappe (Otis. t. tarda L., 1758) - eine Computersimulation. Naturschutz und Landschaftsplege in Brandenburg. Internationaler Workshop: Conservation and Management of the Great Bustard in Europe, Heft 1-2, 91-94.

Suárez-Seoane, S., Osborne, P.E. \& Alonso, J.C. (2002) Large-scale habitat selection by agricultural steppe birds in Spain: identifying species-habitat responses using Generalised Additive Models. Journal of Applied Ecology, 39, 755-771.

Thomas, J. (2000) The great bustard in Wiltshire: flight into extinction? Wiltshire Archaeological \& Natural History Magazine, 93, 63-70.

Wilson, J.D., Morris, A.J., Arroyo, B.E., Clark, S.C. \& Bradbury, R.B. (1999) A review of the abundance and diversity of invertebrate and plant foods of granivorous birds in northern Europe in relation to agricultural change. Agriculture, Ecosystems and the Environment, 75, 13-30.

Yarrell, A. (1882-84) A History of British Birds. Volume III. Revised and enlarged by Howard Saunders. Van Voorst, London, UK.

\section{Biographical sketch}

Patrick Osborne's research focuses on spatial ecology and conservation science, particularly in relation to dryland birds. He is a member of IUCN's Specialist Group on bustards and is on the Council of the Great Bustard Group. It was for the latter organization that he pulled together existing knowledge on great bustards to judge whether reintroduction to Britain should be attempted. 